\title{
Pengaruh Disiplin Kerja, Lingkungan Kerja, dan Komitmen Organisasional terhadap Kinerja Karyawan: Studi pada Rumah Sakit Islam Banjarmasin
}

\section{Burhannudin \\ Mohammad Zainul \\ Muhammad Harlie}

Manajemen, Universitas Islam Kalimantan Muhammad Arsyad Al Banjari Banjarmasin, Indonesia

Email korespondensi: burhanvirgo@gmail.com

\begin{abstract}
This study aims to examine the effect of work discipline, work environment, and organizational commitment on employee performance at the Banjarmasin Islamic Hospital. This research was conducted on non-medical employees of the Banjarmasin Islamic Hospital. There are 55 respondents who have been selected as samples using the Slovin formula. The method used in this research is survey, while the type of research is classified as explanatory research. The method of data collection used a questionnaire with a Likert scale. Data analysis in this research using multiple linear regression, hypothesis testing, and coefficient of determination are assisted by IBM Version 24 Statistical Product and Service Solutions (SPSS). The results show that work discipline, work environment, and organizational commitment has a partial effect on employee performance at Banjarmasin Islamic Hospital. Then, the three independent variables have a simultaneous effect on employee performance at Banjarmasin Islamic Hospital.
\end{abstract}

Keywords: Work discipline, work environment, organizational commitment, employee performance.

Abstrak. Penelitian ini bertujuan untuk menguji pengaruh disiplin kerja, lingkungan kerja, dan komitmen organisasional terhadap kinerja karyawan pada Rumah Sakit Islam Banjarmasin. Penelitian ini dilakukan pada karyawan non-medis Rumah Sakit Islam Banjarmasin. Responden yang terpilih berjumlah 55 orang sebagai sampel dengan menggunakan rumus Slovin. Penelitian ini menggunakan metode survei, sedangkan jenis penelitian ini termasuk explanatory research. Metode pengumpulan data dalam penelitian ini menggunakan kuesioner dengan skala Likert. Analisis data menggunakan regresi linier berganda, uji hipotesis, dan koefisien determinasi yang dibantu dengan penggunaan alat pengolah data Statistical Product and Service Solutions (SPSS) IBM Versi 24. Hasil penelitian menunjukkan bahwa disiplin kerja, lingkungan kerja, dan komitmen organisasional berpengaruh secara parsial terhadap kinerja karyawan pada 
Rumah Sakit Islam Banjarmasin, serta ketiga variabel independen tersebut berpengaruh secara simultan terhadap kinerja karyawan pada Rumah Sakit Islam Banjarmasin.

Kata kunci: Disiplin kerja, lingkungan kerja, komitmen organisasional, kinerja karyawan.

Article Info:

Received: December 10, 2018

Accepted: March 10, 2019

Available Online: June 13, 2019

DOI: http://dx.doi.org/10.30588/425

\section{LATAR BELAKANG}

Manajemen sumber daya manusia (MSDM) merupakan upaya dalam mengelola orang-orang dalam suatu organisasi guna mencapai tujuan usahanya. Edison et al. (2017) menyampaikan bahwa manajemen sumber daya manusia merupakan manajemen yang memfokuskan anggotanya melalui berbagai langkah strategis dalam rangka meningkatkan kinerja karyawan menuju pengoptimalan tujuan organisasi. Saat ini, globalisasi menuntut potensi sumber daya manusia yang mampu bersaing dan berkualitas dalam skala yang besar. Lebih lanjut, Hasibuan (2009) dalam Edison et al. (2017) menjelaskan bahwa perkembangan MSDM didorong oleh kemajuan peradaban, pendidikan, ilmu pengetahuan, dan tuntutan daya saing produksi barang dan jasa yang dihasilkan. Oleh karena itu, upaya mendayagunakan sumber daya manusia secara maksimal diperlukan untuk menghadapi fenomena tersebut dengan memperhatikan kinerja karyawannya. Tanpa kinerja yang baik dan optimal, tujuan organisasi tidak akan tercapai sesuai yang diharapkan. Begitu pentingnya sumber daya manusia dalam organisasi ditegaskan oleh Fajar dan Heru (2010) yang menyatakan bahwa arti penting manajemen sumber daya manusia bagi organisasi adalah upaya menghindarkan organisasi dari rendahnya kinerja karyawan dalam melaksanakan pekerjaanya.

Sedarmayanti (2017) memberikan pengertian bahwa kinerja karyawan merupakan hasil kerja yang diberikan kepada seseorang atau kelompok orang dalam suatu organisasi sesuai dengan wewenang dan tanggung jawab masing-masing dalam rangka mencapai tujuan organisasi, secara legal, tidak melanggar hukum, serta sesuai moral dan etika. Oleh karena itu, tujuan organisasi perlu dicapai melalui kinerja yang baik dan optimal. Untuk mencapainya, upaya yang dilakukan diawali dengan memperhatikan faktor-faktor yang mempengaruhi kinerja karyawan. Berdasarkan data penilaian kinerja karyawan pada Rumah Sakit Islam Banjarmasin (RSIB) pada tahun 2017, karyawan produktif berjumlah 43 orang, cukup produktif 36 orang, sangat produktif 23 orang, dan kurang produktif 20 orang. Data yang menunjukkan masih adanya karyawan kurang produktif merupakan permasalahan bagi RSIB dalam pencapaian tujuannya. Banyak faktor-faktor yang mempengaruhi hal tersebut, di antaranya adalah disiplin kerja, lingkungan kerja, dan komitmen organisasional karyawan.

Kajian empiris terkait disiplin kerja yang dilakukan oleh Husain (2018) menunjukan bahwa disiplin kerja berpengaruh positif dan signifikan terhadap kinerja karyawan. Namun, hasil penelitian berbeda ditunjukkan oleh Likdanawati et al. (2018) yang menyatakan bahwa disiplin kerja tidak berpengaruh terhadap kinerja karyawan. Selanjutnya, kajian empiris terkait lingkungan kerja yang dilakukan oleh Pratama dan Wismar'ein (2018) menunjukkan bahwa lingkungan kerja memiliki pengaruh positif 
dan signifikan terhadap kinerja karyawan. Hasil ini berbeda dengan penelitian Trisofia, et al. (2015) yang menunjukkan bahwa lingkungan kerja memiliki pengaruh negatif terhadap kinerja karyawan. Berikutnya, kajian empiris yang terkait komitmen organisasional oleh Anggraeni dan Rahardja (2018) menunjukkan bahwa komitmen organisasional berpengaruh positif dan signifikan terhadap kinerja karyawan, sedangkan Murty dan Hudiwinarsih (2012) menemukan bahwa komitmen organisasional karyawan berpengaruh tidak signifikan terhadap kinerja karyawan. Dengan demikian, permasalahan dalam penelitian ini adalah apakah disiplin kerja, lingkungan kerja, dan komitmen organisasional karyawan berpengaruh terhadap kinerja karyawan pada Rumah Sakit Islam Banjarmasin?

Berdasarkan uraian latar belakang dan permasalahan di atas, maka tujuan yang ingin dicapai dalam penelitian ini adalah menguji apakah disiplin kerja, lingkungan kerja, dan komitmen organisasional karyawan berpengaruh secara parsial terhadap kinerja karyawan pada RSIB. Selanjutnya, rerangka pemikiran yang digunakan dalam penelitian ini dijelaskan melalui Gambar 1 berikut.

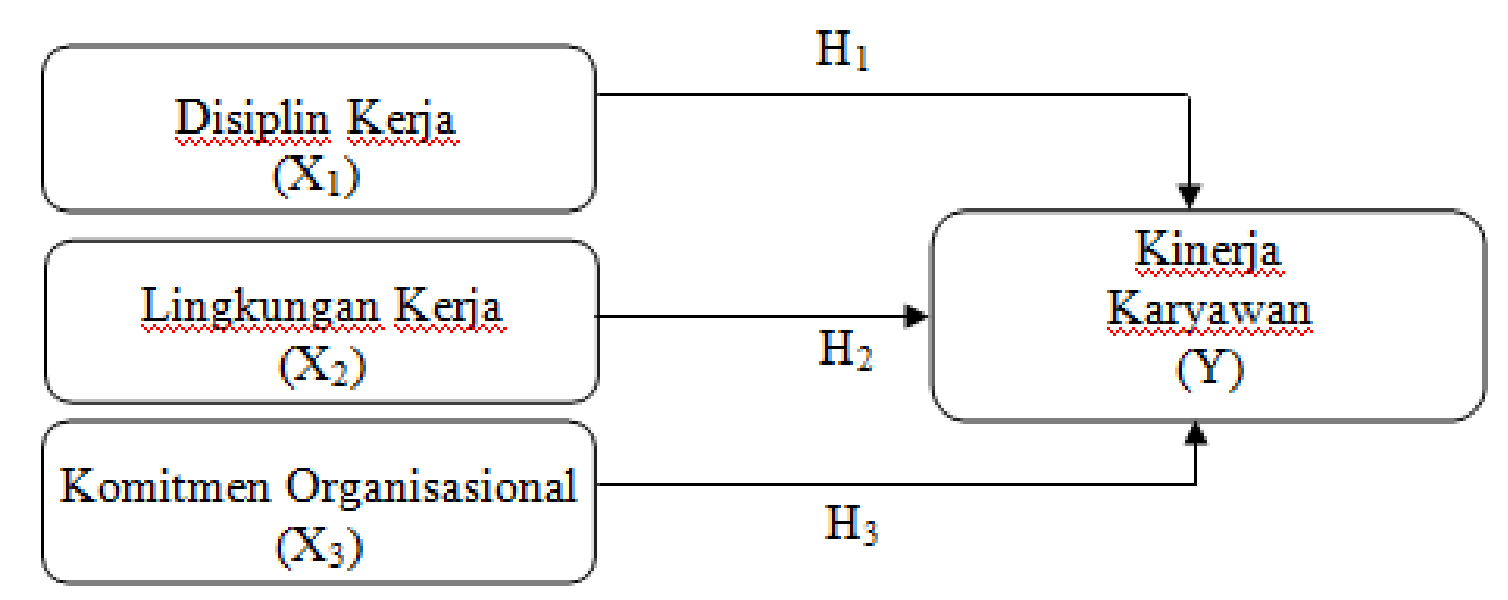

Gambar 1. Kerangka Pemikiran

Berdasarkan rerangka pemikiran tersebut di atas, hipotesis yang diajukan dalam penelitian ini sebagai berikut: $\left(\mathrm{H}_{1}\right)$ Disiplin kerja berpengaruh secara parsial terhadap kinerja karyawan pada Rumah Sakit Islam Banjarmasin; $\left(\mathrm{H}_{2}\right)$ Lingkungan kerja berpengaruh secara parsial terhadap kinerja karyawan pada Rumah Sakit Islam Banjarmasin; dan $\left(\mathrm{H}_{3}\right)$ Komitmen organisasional berpengaruh secara parsial terhadap kinerja karyawan pada Rumah Sakit Islam Banjarmasin.

\section{KAJIAN TEORITIS}

\section{Disiplin Kerja}

Menurut Supomo dan Nurhayati (2018), disiplin kerja diartikan sebagai suatu sikap atau perilaku seorang karyawan dalam suatu organisasi untuk selalu taat, menghargai, dan menghormati berbagai peraturan dan norma yang telah ditetapkan organisasi dalam rangka pencapaian tujuan organisasi. Disiplin kerja yang baik mencerminkan besarnya rasa tanggung jawab seseorang terhadap tugas-tugas yang diamanahkan kepa- 
danya. Hal tersebut akan mendorong semangat kerja dan meningkatkan kinerja karyawan, sehingga berdampak terhadap pencapaian tujuan organisasi. Selanjutnya, Sutrisno (2014) menyebutkan bahwa disiplin kerja adalah perilaku seseorang yang sesuai dengan peraturan, prosedur kerja yang ada atau sikap, tingkah laku, dan perbuatan yang sesuai dengan peraturan organisasi, baik tertulis maupun tidak tertulis. Mangkunegara (2014) menegaskan bahwa disiplin kerja merupakan pelaksanaan manajemen untuk meneguhkan pedoman-pedoman organisasi. Berdasarkan pengertian tersebut, disiplin kerja merupakan sebuah keharusan dan kewajiban yang mutlak untuk diimplementasikan oleh karyawan di suatu organisasi dengan memperhatikan aturan tertulis di dalam organisasi, maupun yang tidak tertulis atau bersifat lisan dengan harapan mereka dapat bekerja dengan penuh tanggung jawab, sehingga tujuan organisasi akan lebih mudah tercapai.

Hasibuan (2009) menjelaskan bahwa faktor-faktor yang mempengaruhi disiplin kerja karyawan adalah sebagai berikut: (a) Tujuan dan kemampuan, yaitu pekerjaan yang dibebankan kepada karyawan harus sesuai dengan kemampuannya, agar ia dapat bersungguh-sungguh dalam mengerjakan pekerjaannya tersebut; (b) Kepemimpinan, yaitu menjadi contoh atau panutan bagi bawahannya; (c) Kompensasi, yaitu besar kecilnya imbalan yang dapat mempengaruhi kedisiplinan kerja karyawan. Sebaliknya, karyawan akan sulit bekerja dengan disiplin tinggi jika kebutuhan primer mereka tidak terpenuhi; (d) Sanksi hukum, yaitu karyawan takut melakukan tindakan indisipliner apabila sanksi hukum lebih ketat, sehingga ketaatan karyawan terhadap peraturan perusahaan menjadi semakin baik; dan (d) Pengawasan, yaitu tindakan yang paling efektif untuk mewujudkan kedisiplinan kerja karyawan. Ada pun indikator disiplin kerja dalam penelitian ini diambil menurut Supomo dan Nurhayati (2018), yaitu keteladanan pimpinan, balas jasa, dan keadilan.

\section{Lingkungan Kerja}

Menurut Sedarmayanti (2017), lingkungan kerja adalah suatu tempat bagi sejumlah kelompok di mana di dalamnya terdapat beberapa fasilitas pendukung untuk mencapai tujuan perusahaan sesuai dengan visi dan misi perusahaan. Sementara itu, Nitisemito (2014) mendefinisikan lingkungan kerja sebagai sumber informasi dan tempat untuk melakukan aktifitas, sehingga kondisi lingkungan kerja yang baik harus diwujudkan agar karyawan merasa lebih betah dan nyaman di dalam ruang kerja untuk menyelesaikan pekerjaannya, sehingga tingkat efisiensi yang tinggi dapat tercapai. Sedarmayanti (2014) menyebutkan bahwa kondisi lingkungan kerja yang baik, apabila manusia dapat melaksanakan kegiatan kerjanya secara optimal, sehat, aman, dan nyaman. Kesesuaian lingkungan kerja dapat dirasakan akibatnya dalam jangka panjang, sedangkan lingkungan kerja yang kurang baik dapat mengubah tenaga kerja dan waktu yang lebih banyak, serta tidak mendukung diperolehnya rancangan sistem kerja yang efisien. Dengan demikian, lingkungan kerja merupakan lingkungan aktivitas di mana karyawan melakukan pekerjaan yang dapat mempengaruhi pencapaian tujuan organisasi dan menciptakan kenyamanan dalam melakukan tugas-tugas mereka.

Banyak faktor yang dapat mempengaruhi lingkungan kerja karyawan. Nitisemito (2014) menjelaskan bahwa faktor yang mempengaruhi lingkungan kerja adalah warna, kebersihan, pertukaran udara, penerangan, keamanan, dan kebisingan. Ada pun manfaat lingkungan kerja adalah kemampuan menciptakan gairah kerja, sehingga produktifitas kerja meningkat (Arep dkk., 2003). Sementara itu, manfaat yang diperoleh karena bekerja dengan orang-orang yang termotivasi adalah pekerjaan tersebut dapat diselesai- 
kan dengan tepat. Artinya, pekerjaan dapat diselesaikan sesuai standar yang benar dan dalam skala waktu yang ditentukan. Kinerja akan dipantau oleh individu yang bersangkutan dan tidak membutuhkan terlalu banyak pengawasan, serta semangat kerja yang tinggi. Indikator lingkungan kerja dalam penelitian ini mendasarkan pendapat Sedarmayanti (2017), sebagai berikut: Perhatian dan dukungan pimpinan, yaitu sejauh mana karyawan merasakan bahwa pimpinan sering memberikan penghargaan dan perhatian serta menghargai mereka; Kerjasama antarkelompok, yaitu sejauh mana karyawan merasakan adanya kerjasama yang baik di antara kelompok yang ada; dan Kelancaran komunikasi, yaitu sejauh mana karyawan merasakan adanya komunikasi yang baik, terbuka, dan lancar baik antarrekan kerja maupun pimpinan.

\section{Komitmen Organisasional}

Moorhead dan Griffin (2013) mengartikan komitmen organisasional sebagai sikap yang mencerminkan sejauh mana individu mengenal dan terikat pada organisasinya. Sementara itu, Wirawan (2013) berpendapat bahwa komitmen organisasional dapat digunakan untuk memprediksi variabel-variabel yang berhubungan dengan organisasi, seperti turnover (pindah kerja), perilaku kewargaan organisasi, kepuasan kerja, dan kinerja. Banyak faktor yang mempengaruhi komitmen organisasional. Steers dan Porter (dalam Sopiah, 2008) mengemukakan bahwa komitmen organisasional dapat dilihat dari tiga faktor, yaitu: kepercayaan dan penerimaan yang kuat atas tujuan dan nilai-nilai organisasi; kemauan untuk mengusahakan tercapainya kepentingan organisasi; dan keinginan kuat untuk mempertahankan keanggotaan organisasi. Menurut Hunt dan Morgan (dalam Sopiah, 2008), karyawan memiliki komitmen organisasional yang tinggi, apabila ia memiliki kepercayaan dan menerima tujuan organisasi, memiliki keinginan untuk berusaha ke arah pencapaian tujuan organisasi, dan memiliki keinginan kuat untuk bertahan sebagai anggota organisasi.

Selanjutnya, Robbins dan Judge (2008) menguraikan tiga hal yang digunakan untuk mengukur komitmen karyawan pada organisasi, yaitu: Komitmen afektif (Affective commitment) yang terjadi apabila karyawan ingin menjadi bagian dari organisasi karena adanya ikatan emosional; Komitmen berkelanjutan (Continuance commitment) akan muncul apabila karyawan tetap bertahan pada suatu organisasi karena mereka membutuhkan gaji dan keuntungan-keuntungan lain, atau tidak menemukan pekerjaan lain; dan Komitmen normatif (Normative commitment) timbul dari nilai-nilai di dalam diri karyawan. Karyawan akan bertahan menjadi anggota organisasi, karena adanya kesadaran bahwa komitmen terhadap organisasi merupakan hal yang seharusnya dilakukan. Ada pun indikator komitmen organisasional dalam penelitian ini didasarkan pada Ghoniyah dan Masurip (2011), yaitu: Tetap menjadi anggota organisasi; Kesediaan berusaha demi kepentingan organisasi; dan Kepercayaan dan penerimaan kuat terhadap nilai-nilai dan tujuan organisasi.

\section{Kinerja}

Marwansyah (2016) menyebutkan bahwa kinerja adalah pencapaian atau prestasi seseorang berkenaan dengan tugas-tugas yang dibebankan kepadanya. Sementara, Rivai dan Sagala (2013) mendefinisikan kinerja karyawan sebagai perilaku nyata yang ditampilkan setiap karyawan sebagai prestasi kerja yang dihasilkan sesuai dengan perannya di dalam perusahaan. Berdasarkan pengertian tersebut, kinerja karyawan merupakan hasil kerja, baik secara kuantitas ataupun kualitas karyawan yang didapatkan melalui penyelesaian tugas-tugas yang diberikan sesuai dengan wewenang dan tang- 
gung jawab mereka masing-masing. Banyak faktor yang dapat mempengaruhi kinerja karyawan, seperti yang dijelaskan oleh Sedarmayanti (2014), antara lain: Sikap dan mental (motivasi kerja, disiplin kerja, dan etika kerja); Pendidikan; Ketrampilan; Manajemen kepemimpinan; Tingkat penghasilan; Gaji dan kesehatan; Jaminan sosial; Iklim kerja; Sarana dan prasarana; Teknologi; dan Kesempatan berprestasi. Di sisi lain, Tika (2006) menyatakan bahwa kinerja karyawan dipengaruhi oleh dua faktor, yaitu: Faktor intern yang terdiri atas kecerdasan, ketrampilan, kestabilan emosi, motivasi, persepsi peran, kondisi keluarga, kondisi fisik, dan karakteristik kelompok kerja; dan Faktor ekstern yang terdiri atas peraturan ketenagakerjaan, keinginan pelanggan, pesaing, nilai-nilai sosial, serikat pekerja, kondisi ekonomi, perubahan lokasi kerja, dan kondisi pasar. Ada pun indikator untuk mengukur kinerja karyawan di dalam penelitian ini didasarkan pada pendapat Mangkunegara (2014) yang menjelaskan indikator kinerja karyawan terdiri atas: Kualitas kerja; Kuantitas kerja; dan Ketepatan waktu.

\section{METODE PENELITIAN}

Penelitian ini dilakukan pada Rumah Sakit Islam Banjarmasin, Kalimantan Selatan. Ada pun populasi dalam penelitian ini adalah seluruh karyawan non-medis di RSIB yang berjumlah 122 karyawan. Rincian populasi karyawan non-medis pada penelitian ini ditampilkan pada Tabel 1 berikut.

Tabel 1. Karyawan Bagian Non-Medis Rumah Sakit Islam Banjarmasin Tahun 2018

\begin{tabular}{lcc}
\multicolumn{1}{c}{ Divisi } & Jumlah & Persentase \\
\hline Administrasi \& Umum & 46 & $38 \%$ \\
\hline Keuangan & 20 & $16 \%$ \\
\hline Pembantu Keperawatan & 38 & $31 \%$ \\
\hline Penunjang & 18 & $15 \%$ \\
\hline & 122 & $100 \%$ \\
\hline
\end{tabular}

Sumber: Bagian SDM \& Diklat RSIB, 2018.

Penentuan sampel dalam penelitian ini menggunakan rumus Slovin (Sugiyono, 2017) dengan persentase kelonggaran kesalahan pengambilan sampel sebesar $10 \%$. Perhitungan sampel dilakukan berdasarkan rumus Slovin berikut ini:

$$
\begin{aligned}
& \mathrm{n}=\frac{\mathrm{N}}{1+\mathrm{N}(\mathrm{e})^{2}} \\
& \mathrm{n}=\frac{122}{1+122(0,01)} \\
& \mathrm{n}=\frac{122}{2.220} \\
& \mathrm{n}=55 \text { sampel }
\end{aligned}
$$

Keterangan:

$\mathrm{n} \quad=$ ukuran sampel/jumlah responden

$\mathrm{N} \quad=$ ukuran populasi

e $\quad=$ estimasi error $10 \%$.

Berdasarkan perhitungan tersebut, jumlah sampel yang harus diambil sebanyak 55 sampel. Teknik pendistribusian responden menggunakan quota sampling yaitu salah 
satu teknik non-probability sampling. Teknik ini digunakan karena ukuran sampel yang akan diambil telah ditetapkan (Sugiyono, 2017). Data distribusi jumlah sampel ditunjukkan pada Tabel 2 berikut.

Tabel 2. Distribusi Jumlah Sampel dengan Quota Sampling

\begin{tabular}{|c|c|c|c|}
\hline Divisi & Jumlah & Persentase & Sampel \\
\hline Administrasi dan Umum & 46 & $38 \%$ & 21 \\
\hline Keuangan & 20 & $16 \%$ & 9 \\
\hline Pembantu Keperawatan & 38 & $31 \%$ & 17 \\
\hline Penunjang & 18 & $15 \%$ & 8 \\
\hline Total & 122 & $100 \%$ & 55 \\
\hline
\end{tabular}

Sumber: Data sekunder diolah, 2018.

Berdasarkan Tabel 2 di atas, pendistribusian sampel di tiap-tiap divisi di lingkungan RSIB adalah Divisi Administrasi dan Umum sebanyak 21 responden, Divisi Keuangan 9 responden, Divisi Pembantu Keperawatan 17 responden, dan Divisi Penunjang 8 responden. Metode pengumpulan data yang digunakan dalam penelitian ini adalah survei, sedangkan jenis penelitian ini tergolong dalam explanatory research. Pengumpulan data menggunakan kuesioner dengan skala Likert. Teknik analisis data menggunakan regresi linier berganda, uji hipotesis, dan koefisien determinasi dengan menggunakan alat bantu Statistical Product and Service Solutions (SPSS) IBM Versi 24.

\section{HASIL DAN PEMBAHASAN}

\section{Diskripsi Responden}

\section{Diskripsi Responden Berdasarkan Jenis Kelamin}

Diskripsi responden dalam penelitian ini berdasarkan jenis kelamin dapat dilihat pada Tabel 3 berikut. Berdasarkan Tabel 3, sebagian besar responden berjenis kelamin perempuan, yaitu 38 orang atau $69,1 \%$, sedangkan responden laki-laki berjumlah 17 orang atau $30,9 \%$.

Tabel 3. Responden Berdasarkan Jenis Kelamin

\begin{tabular}{lccc}
\hline \multicolumn{2}{c}{ Jenis Kelamin } & Frekuensi & Persentase (\%) \\
\hline Laki-Laki & & 17 & 30,9 \\
\hline Perempuan & Total & 38 & 69,1 \\
\hline \multicolumn{2}{c}{} & 55 & 100,0 \\
\hline
\end{tabular}

Sumber: Data primer diolah, 2018.

\section{Diskripsi Responden Berdasarkan Usia}

Diskripsi responden dalam penelitian ini berdasarkan usia tersaji pada Tabel 4 . Sebagian besar responden berusia 30-49 tahun yaitu 35 orang atau 63,6\%, kemudian disusul responden yang berusia 25-29 tahun berjumlah 13 orang atau 23,6\%, responden 
berusia lebih dari 50 tahun berjumlah 6 orang atau 10,9\%, sedangkan responden berusia kurang dari 25 tahun berjumlah 1 orang atau $1,8 \%$.

Tabel 4. Responden Berdasarkan Usia

\begin{tabular}{ccc}
\hline Usia Responden & Frekuensi & Persentase (\%) \\
\hline$<25$ tahun & 1 & 1,8 \\
\hline$>50$ tahun & 6 & 10,9 \\
\hline $25-29$ tahun & 13 & 23,6 \\
\hline $30-49$ tahun & 35 & 63,6 \\
\hline Total & 55 & 100,0 \\
\hline
\end{tabular}

Sumber: Data primer diolah, 2018.

\section{Diskripsi Responden Berdasarkan Pendidikan}

Diskripsi responden dalam penelitian ini berdasarkan pendidikan ditunjukkan pada Tabel 5. Berdasarkan Tabel 5 tersebut, sebagian besar responden berpendidikan SMA (Sekolah Menengah Atas) berjumlah 22 orang atau 40\%. Responden berpendidikan tinggi S1 (Strata 1) berjumlah 22 orang atau 40\%, responden berpendidikan diploma berjumlah 10 orang atau 18,2\%, sedangkan responden berpendidikan tinggi S-2 (Strata 2) paling kecil yaitu 1 orang atau $1,8 \%$.

\section{Tabel 5. Responden Berdasarkan Pendidikan}

\begin{tabular}{lcc}
\hline Tingkat Pendidikan & Frekuensi & Persentase (\%) \\
\hline SMA & 22 & 40,0 \\
\hline Diploma & 10 & 18,2 \\
\hline S1 & 22 & 40,0 \\
\hline S2 & 1 & 1,8 \\
\hline Total & 55 & 100,0 \\
\hline
\end{tabular}

Sumber: Data primer diolah, 2018.

\section{Diskripsi Responden Berdasarkan Unit Kerja}

Diskripsi responden dalam penelitian ini berdasarkan pada unit kerjanya ditunjukkan pada Tabel 6. Berdasarkan Tabel 6 tersebut, sebagian besar responden berada pada unit kerja di Divisi Administrasi dan Umum yaitu 21 orang atau 38,2\%. Responden di unit kerja Divisi Penunjang berjumlah 17 orang atau 30,9\%, responden di unit kerja Divisi Keuangan berjumlah 9 orang atau 16,4\%, dan responden di unit kerja Divisi Pembantu Keperawatan berjumlah 8 orang atau $14,5 \%$.

Tabel 6. Responden Berdasarkan Unit Kerja

\begin{tabular}{|c|c|c|}
\hline Unit Kerja & Frekuensi & Persentase $(\%)$ \\
\hline Administrasi dan Umum & 21 & 38,2 \\
\hline Keuangan & 9 & 16,4 \\
\hline Pembantu Keperawatan & 8 & 14,5 \\
\hline Penunjang & 17 & 30,9 \\
\hline Total & 55 & 100,0 \\
\hline
\end{tabular}

Sumber: Data primer diolah, 2018. 


\section{Diskripsi Responden Berdasarkan Masa Kerja}

Diskripsi responden dalam penelitian berdasarkan masa kerja disajikan pada Tabel 7. Berdasarkan Tabel 7. tersebut di atas, dapat diketahui bahwa sebagian besar responden masa kerja $>10$ tahun yaitu berjumlah 35 orang atau $64,7 \%$. Masa kerja 5-9 tahun berjumlah 14 orang atau $25,5 \%$ dan masa kerja 1-4 tahun berjumlah 6 orang atau $10,9 \%$.

Tabel 7. Responden Berdasarkan Masa Kerja

\begin{tabular}{ccc}
\hline Masa Kerja & Frekuensi & Persentase $(\%)$ \\
\hline 10 Tahun & 35 & 63,6 \\
\hline 1-4 Tahun & 6 & 10,9 \\
\hline 5-9 Tahun & 14 & 25,5 \\
\hline Total & 55 & 100,0 \\
\hline
\end{tabular}

Sumber: Data primer diolah, 2018.

\section{Uji Validitas dan Reliabilitas}

Uji validitas pada penelitian ini dilakukan dengan mengkorelasikan skor butir dengan total butir tersebut. Jika koefisien antara butir dengan total butir sama atau di atas 0,3 , maka butir tersebut dinyatakan valid, tetapi jika nilai korelasinya di bawah 0,3 maka butir tersebut dinyatakan tidak valid (Sugiyono, 2017). Hasil uji validitas instrumen penelitian ini dapat dilihat pada Tabel 8. Tabel 8 menunjukkan bahwa nilai korelasi pada indikator disiplin kerja $\left(\mathrm{X}_{1}\right)$, lingkungan kerja $\left(\mathrm{X}_{2}\right)$, komitmen organisasional $\left(\mathrm{X}_{3}\right)$, dan kinerja karyawan $(\mathrm{Y})$ lebih besar dari 0,3 , sehingga semua variabel yang diteliti yaitu $\mathrm{X}_{1}, \mathrm{X}_{2}, \mathrm{X}_{3}$, dan $\mathrm{Y}$ dinyatakan valid dan dapat dijadikan sebagai alat ukur yang tepat.

Tabel 8. Hasil Uji Validitas

\begin{tabular}{lcccc}
\hline Variabel & & \multicolumn{2}{c}{ Korelasi } & \multicolumn{2}{c}{ Standar Keterangan } \\
\hline \multirow{3}{*}{ Disiplin_Kerja $\left(\mathrm{X}_{1}\right)$} & $\mathrm{X} 1.1$ & 0,749 & 0,3 & Valid \\
\cline { 2 - 5 } & $\mathrm{X} 1.2$ & 0,830 & 0,3 & Valid \\
\cline { 2 - 5 } & $\mathrm{X} 1.3$ & 0,645 & 0,3 & Valid \\
\hline \multirow{2}{*}{ Lingkungan_Kerja $\left(\mathrm{X}_{2}\right)$} & $\mathrm{X} 2.1$ & 0,370 & 0,3 & Valid \\
\cline { 2 - 5 } & $\mathrm{X} 2.2$ & 0,324 & 0,3 & Valid \\
\cline { 2 - 5 } & $\mathrm{X} 2.3$ & 0,370 & 0,3 & Valid \\
\hline \multirow{2}{*}{ Komitmen_Organisasional $\left(\mathrm{X}_{3}\right)$} & $\mathrm{X} 3.1$ & 0,618 & 0,3 & Valid \\
\cline { 2 - 5 } & $\mathrm{X} 3.2$ & 0,310 & 0,3 & Valid \\
\cline { 2 - 5 } & $\mathrm{X} 3.3$ & 0,718 & 0,3 & Valid \\
\hline \multirow{2}{*}{ Kinerja_Karyawan $(\mathrm{Y})$} & $\mathrm{Y} 1.1$ & 0,389 & 0,3 & Valid \\
\cline { 2 - 5 } & $\mathrm{Y} 1.2$ & 0,336 & 0,3 & Valid \\
\cline { 2 - 5 } & $\mathrm{Y} 1.3$ & 0,826 & 0,3 & Valid \\
\hline
\end{tabular}

Sumber: Data primer diolah, 2018.

Uji reliabilitas penelitian ini diukur dengan menggunakan uji statistik Cronbach's alpha $(\alpha)$. Suatu variabel dikatakan reliable atau andal, jika memberikan nilai Cronbach's alpha > 0,60 (Sugiyono, 2017). Hasil pengujian reliabilitas penelitian ini disajikan pada Tabel 9. Hasil tersebut menunjukkan bahwa data yang diperoleh memiliki keandalan karena nilai Cronbach's alpha lebih besar dari 0,60, sehingga data yang diperoleh dinyatakan andal. 
Tabel 9. Hasil Uji Reliabilitas

\begin{tabular}{|c|c|c|}
\hline Cronbach's Alpha & $\begin{array}{c}\text { Cronbach's Alpha Based on } \\
\text { Standardized Items }\end{array}$ & N of Items \\
\hline 0,866 & 0,856 & 12 \\
\hline
\end{tabular}

Sumber: Data primer diolah, 2018.

\section{Hasil Uji Asumsi Klasik}

Hasil uji multikolinearitas dapat dilihat pada Tabel 10 berikut. Pengujian ada atau tidaknya gejala multikolinearitas dilakukan dengan melihat nilai VIF (Variance Inflation Factor) dan Tolerance. Apabila nilai VIF di bawah 10,00 dan nilai Tolerance lebih dari 0,100 , maka model regresi tersebut tidak menunjukkan gejala multikolinea-ritas. Hasil perhitungan menunjukkan bahwa nilai VIF dan Tolerance setiap variabel independen dalam penelitian ini lebih kecil dari 10,00 dan nilai tolerance lebih besar dari 0,100 (Tabel 10), sehingga model regresi ini tidak menunjukkan gejala multikolinearitas.

Tabel 10. Hasil Uji Multikolinearitas

\begin{tabular}{|c|c|c|c|c|c|c|c|}
\hline \multirow{2}{*}{\multicolumn{2}{|c|}{ Model }} & \multicolumn{2}{|c|}{$\begin{array}{l}\text { Unstandardized } \\
\text { Coefficients }\end{array}$} & \multirow[t]{2}{*}{$\mathrm{t}$} & \multirow{2}{*}{ Sig. } & \multicolumn{2}{|c|}{ Collinearity Statistics } \\
\hline & & $\mathrm{B}$ & Std. Error & & & Tolerance & VIF \\
\hline \multirow[t]{4}{*}{1} & (Constant) & 2,514 & 0,878 & 2,864 & 0,006 & & \\
\hline & Disiplin_Kerja & 0,245 & 0,060 & 4,102 & 0,000 & 0,410 & 2,437 \\
\hline & Lingkungan_Kerja & 0,344 & 0,077 & 4,455 & 0,000 & 0,796 & 1,256 \\
\hline & Komitmen_Organisasional & 0,171 & 0,082 & 2,084 & 0,042 & 0,358 & 2,796 \\
\hline
\end{tabular}

Sumber: Data primer diolah, 2018.

\section{Scatterplot}

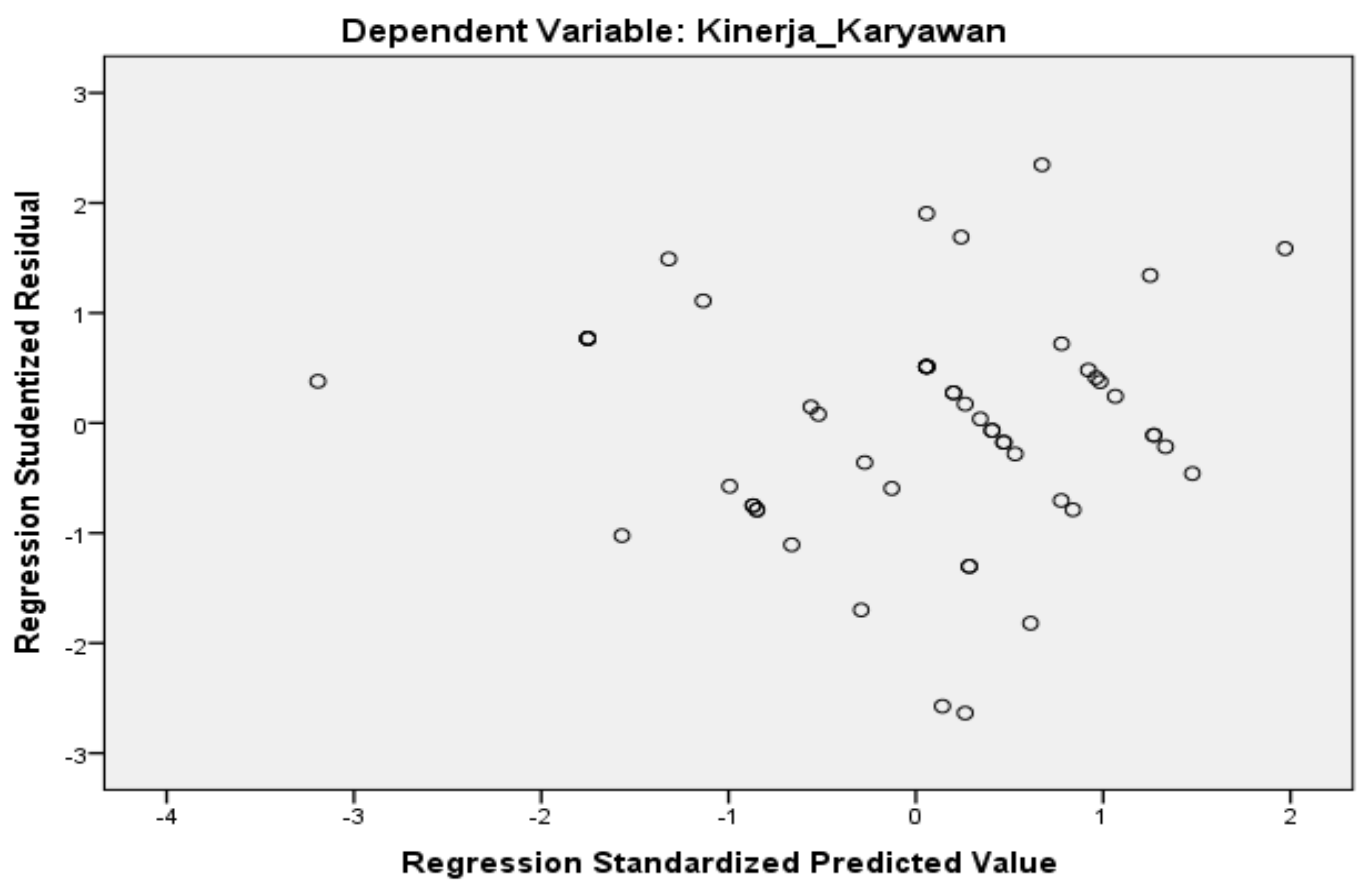

Sumber: Data primer diolah, 2018.

Gambar 2. Scatterplot 
Selanjutnya, pengujian heterokedastisitas dilakukan untuk mengetahui ada tidaknya pola tertentu pada scatterplot, yaitu sumbu $\mathrm{x}$ adalah variabel $\mathrm{Y}$ yang telah diprediksi, sedangkan sumbu y adalah nilai residual (Y prediksi-Y sesungguhnya) yang telah distudentized (Gambar 2). Berdasarkan Gambar 2 tersebut, titik-titik data yang menyebar di atas dan di bawah atau di sekitar angka 0, dan penyebaran titik-titik data yang tidak berpola menunjukkan tidak adanya gejala heterokedastisitas, sehingga model regresi dalam penelitian ini tepat digunakan sebagai model pengukuran.

Uji normalitas dalam penelitian ini dapat dilihat pada tampilan Gambar 3 berikut. Berdasarkan Gambar 3, data menyebar di sekitar garis diagonal dan mengikuti arah garis diagonal tersebut, sehingga hasil uji menunjukkan bahwa model regresi yang digunakan dalam penelitian ini memenuhi asumsi normalitas.

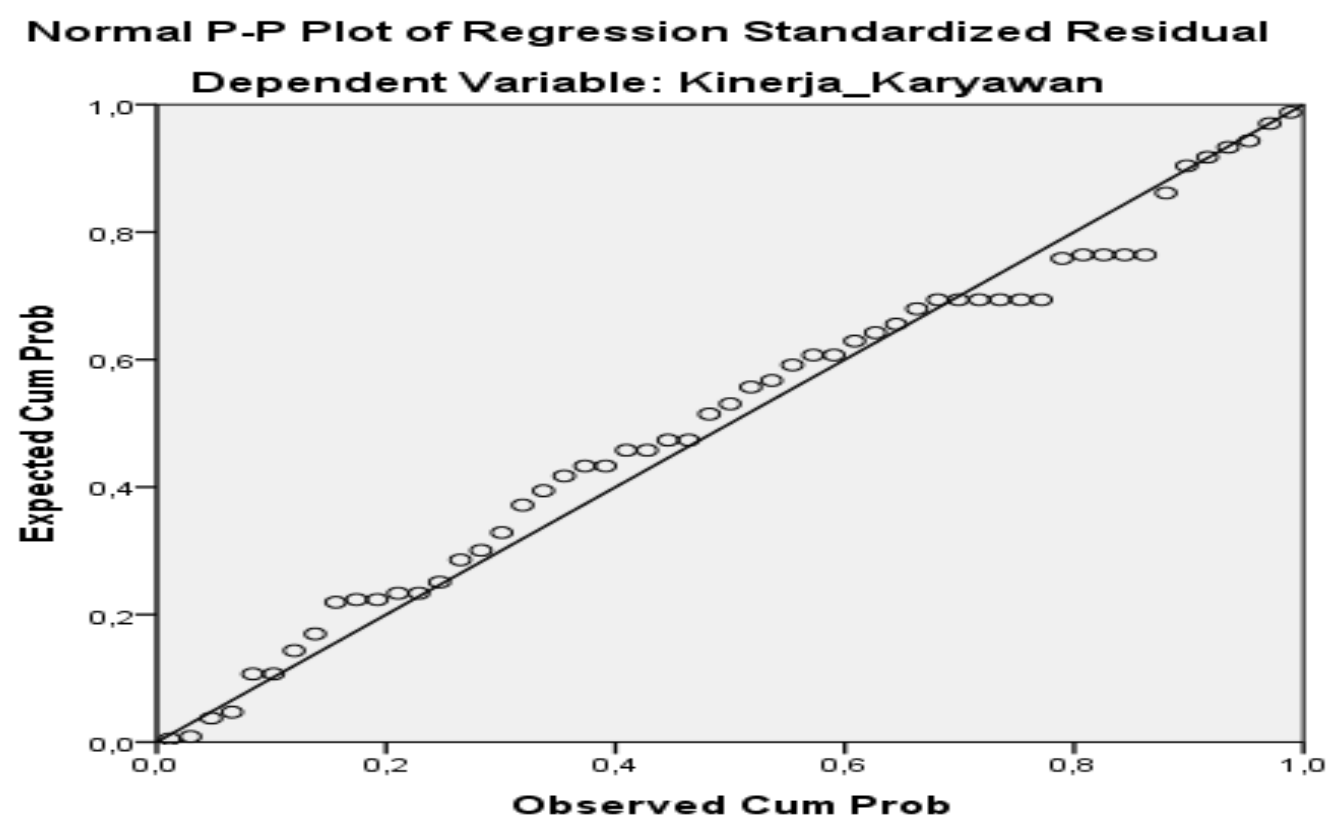

Sumber: Data primer diolah, 2018.

Gambar 3. Normal Probability Plot

\section{Hasil Uji Regresi Linier Berganda}

Hasil pengujian regresi linier berganda dalam penelitian ini tersaji pada Tabel 11 berikut. Berdasarkan Tabel 11, persamaan regresi linier berganda yang diperoleh dalam penelitian ini adalah:

$$
Y=2,514+0,245\left(X_{1}\right)+0,344\left(X_{2}\right)+0,171\left(X_{3}\right)
$$

1. Nilai konstanta sebesar 2,514, yaitu variabel disiplin kerja $\left(X_{1}\right)$, lingkungan kerja $\left(\mathrm{X}_{2}\right)$, dan komitmen organisasional $\left(\mathrm{X}_{3}\right)$ diasumsikan tetap, sehingga kinerja karyawan akan meningkat sebesar 2,514.

2. Nilai koefisien regresi untuk variabel disiplin kerja $\left(X_{1}\right)$ pada persamaan regresi menunjukkan nilai positif 0,245 yaitu jika disiplin kerja meningkat dan variabel bebas lainnya dianggap tetap, maka kinerja karyawan akan meningkat sebesar 0,245. 
3. Nilai koefisien regresi untuk variabel lingkungan kerja $\left(\mathrm{X}_{2}\right)$ pada persamaan regresi menunjukkan nilai positif 0,344 yaitu jika lingkungan kerja meningkat dan variabel bebas lainnya dianggap tetap, maka kinerja karyawan akan meningkat sebesar 0,344.

4. Nilai koefisien regresi untuk variabel komitmen organisasional $\left(\mathrm{X}_{3}\right)$ pada persamaan regresi menunjukkan nilai positif 0,171 yaitu jika komitmen organisasional meningkat dan variabel bebas lainnya dianggap tetap, maka kinerja karyawan akan meningkat sebesar 0,171 .

Tabel 11. Hasil Uji Regresi Linier Berganda

\begin{tabular}{|c|c|c|c|c|c|c|}
\hline \multirow{2}{*}{\multicolumn{2}{|c|}{ Model }} & \multicolumn{2}{|c|}{$\begin{array}{c}\text { Unstandardized } \\
\text { Coefficients }\end{array}$} & \multirow{2}{*}{$\begin{array}{c}\begin{array}{c}\text { Standardized } \\
\text { Coefficients }\end{array} \\
\text { Beta }\end{array}$} & \multirow[t]{2}{*}{$\mathbf{t}$} & \multirow[t]{2}{*}{ Sig. } \\
\hline & & $B$ & Std. Error & & & \\
\hline \multirow[t]{4}{*}{1} & (Constant) & 2,514 & 0,878 & & 2,864 & 0,006 \\
\hline & Disiplin_Kerja & 0,245 & 0,060 & 0,457 & 4,102 & 0,000 \\
\hline & Lingkungan_Kerja & 0,344 & 0,077 & 0,356 & 4,455 & 0,000 \\
\hline & Komitmen_Organisasional & 0,171 & 0,082 & 0,249 & 2,084 & 0,042 \\
\hline
\end{tabular}

Sumber: Data primer diolah, 2018.

\section{Hasil Uji Hipotesis}

\section{Uji t (Parsial)}

Hasil uji t digunakan untuk menguji pengaruh secara parsial dari masing-masing variable bebas. Dasar pengambilan keputusan sebagai berikut: (1) Jika nilai Sig < 0,05 maka variabel bebas berpengaruh signifikan terhadap variabel terikat; (2) Jika nilai Sig $>0,05$ maka variabel bebas tidak berpengaruh signifikan terhadap variabel terikat. Hasil uji $\mathrm{t}$ (parsial) penelitian ini dapat dilihat pada Tabel $11 \mathrm{di}$ atas.

Berdasarkan hasil pengujian yang telah dilakukan, nilai $\mathrm{t}$ hitung untuk variabel disiplin kerja $\left(\mathrm{X}_{1}\right)$ adalah 4,102 dengan hasil signifikansinya $0,000<0,05$ dan berdasarkan perbandingan $\mathrm{t}_{\text {hitung }}$ dengan $\mathrm{t}_{\text {tabel }}\left(\mathrm{t}_{\text {tabel }} \alpha=0,05, \mathrm{df}=51\right)$ didapat $\mathrm{t}_{\text {hitung }} 4,102$ lebih besar daripada $t_{\text {tabel }} 1,67528(4,102>1,67528)$, maka hipotesis pertama $\left(\mathrm{H}_{1}\right)$ yang menyatakan terdapat pengaruh disiplin kerja secara parsial terhadap kinerja karyawan pada RSIB dapat diterima.

Hasil uji t hitung untuk variabel lingkungan kerja $\left(\mathrm{X}_{2}\right)$ adalah 4,455 dengan hasil signifikansinya $0,000<0,05$ dan berdasarkan perbandingan $t_{\text {hitung }}$ dengan $t_{\text {tabel }}\left(t_{\text {tabel }}\right.$ $\alpha=0,05, \mathrm{df}=51)$ diperoleh $\mathrm{t}_{\text {hitung }} 4,455$ lebih besar daripada $t_{\text {tabel }} 1,67528(4,455>$ 1,67528), maka hipotesis kedua $\left(\mathrm{H}_{2}\right)$ yang menyatakan adanya pengaruh lingkungan kerja secara parsial terhadap kinerja karyawan pada RSIB dapat diterima.

Selanjutnya, perhitungan nilai t hitung untuk variabel komitmen organisasional $\left(\mathrm{X}_{3}\right)$ adalah 2,084 dengan hasil signifikansinya $0,000<0,05$ dan berdasarkan perbandingan $t_{\text {hitung }}$ dengan $t_{\text {tabel }}\left(t_{\text {tabel }} \alpha=0,05, d f=51\right)$ diperoleh $t_{\text {hitung }} 2,084$ lebih besar daripada $\mathrm{t}_{\text {tabel }} 1,67528(2,084>1,67528)$, maka hipotesis ketiga $\left(\mathrm{H}_{3}\right)$ yang menyatakan terdapat pengaruh komitmen organisasional secara parsial terhadap kinerja karyawan pada RSIB dapat diterima.

\section{Koefisien Determinasi}

Koefisien determinasi menjelaskan variasi pengaruh variabel-variabel bebas terhadap variabel terikatnya atau proporsi pengaruh seluruh variabel bebas terhadap variabel 
terikat. Nilai koefisien determinasi dapat diukur menggunakan Adjusted $R$-Square yang dapat dilihat pada Tabel 12 berikut.

Tabel 12. Koefisien Determinasi $\left(\mathbf{R}^{2}\right)$

\begin{tabular}{|c|c|c|c|}
\hline Model & R & R Square & Adjusted R-Square \\
\hline 1 & 0,860 & 0,740 & 0,725 \\
\hline
\end{tabular}

Sumber: Data primer diolah, 2018.

Tabel 12 di atas menunjukkan bahwa Adjusted R-Square sebesar 0,725 adalah proporsi pengaruh variabel $\mathrm{X}_{1}$ (disiplin kerja), $\mathrm{X}_{2}$ (lingkungan kerja) dan komitmen organisasional terhadap variabel kinerja $(\mathrm{Y})$. Artinya, disiplin kerja, lingkungan kerja dan komitmen organisasional memiliki proporsi pengaruh terhadap kinerja sebesar $72,5 \%$, sedangkan sisanya sebesar 27,5\% (100\%-72,5\%) merupakan proporsi pengaruh oleh variabel lain yang tidak digunakan dalam penelitian ini.

\section{Pembahasan}

\section{Pengaruh Disiplin Kerja Terhadap Kinerje Karyawan}

Koefisien regresi variabel disiplin kerja $\left(\mathrm{X}_{1}\right)$ sebesar 0,245 menunjukkan hubungan positif atau searah dengan kinerja karyawan RSIB. Hasil uji t (parsial) menunjukkan bahwa variabel disiplin kerja $\left(\mathrm{X}_{1}\right)$ memiliki hasil signifikan, sehingga hipotesis pertama $\left(\mathrm{H}_{1}\right)$, yaitu terdapat pengaruh disiplin kerja secara parsial positif dan signifikan terhadap kinerja karyawan pada RSIB diterima. Hasil penelitian tersebut mendukung hasil penelitian yang dilakukan oleh Husain (2018). Selanjutnya, hasil tersebut juga memperkuat pendapat Supomo dan Nurhayati (2018) bahwa disiplin kerja adalah suatu sikap atau perilaku karyawan dalam suatu organisasi untuk selalu taat, menghargai, dan menghormati berbagai peraturan dan norma yang telah ditetapkan organisasi dalam rangka pencapaian tujuan organisasi. Disiplin kerja yang baik mencerminkan besarnya rasa tanggung jawab karyawan terhadap tugas-tugas yang diamanahkan kepadanya. Kedisiplinan tersebut akan mendorong semangat kerja dan meningkatkan kinerja karyawan, sehingga memberikan dampak terhadap pencapaian tujuan organisasi.

\section{Pengaruh Lingkungan Kerja Secara Parsial Terhadap Kinerja Karyawan}

Koefisien regresi variabel lingkungan kerja $\left(\mathrm{X}_{2}\right)$ adalah sebesar 0,344 yang menunjukkan hubungan positif atau searah dengan kinerja karyawan RSIB. Hasil uji t (parsial) menunjukkan bahwa variabel lingkungan kerja $\left(\mathrm{X}_{2}\right)$ memiliki hasil signifikan, sehingga hipotesis kedua $\left(\mathrm{H}_{2}\right)$, yaitu terdapat pengaruh lingkungan kerja secara parsial positif dan signifikan terhadap kinerja karyawan pada RSIB diterima. Hasil penelitian tersebut mendukung hasil penelitian yang dilakukan Pratama dan Wismar'ein (2018) yang menunjukkan lingkungan kerja memiliki pengaruh positif dan signifikan terhadap kinerja karyawan. Hasil tersebut juga memperkuat pendapat Sedarmayanti (2017), yaitu lingkungan kerja adalah suatu tempat bagi sejumlah kelompok di mana di dalamnya terdapat beberapa fasilitas pendukung untuk mencapai tujuan perusahaan sesuai dengan visi dan misi perusahaan. Dengan kondisi lingkungan kerja yang baik, karyawan dapat melaksanakan kegiatan secara optimal, sehat, aman, dan nyaman. Kesesuaian lingkung- 
an kerja dapat dilihat akibatnya dalam jangka panjang. Lebih jauh lagi, lingkungan kerja yang kurang baik dapat menyebabkan tenaga kerja dan waktu yang tidak efisien.

\section{Pengaruh Komitmen Organisasional Secara Parsial Terhadap Kinerja Karyawan}

Koefisien regresi variabel komitmen organisasional $\left(\mathrm{X}_{3}\right)$ adalah sebesar 0,171 yang menunjukkan hubungan positif atau searah dengan kinerja karyawan RSIB. Hasil uji t (parsial) menunjukkan bahwa variabel komitmen organisasional $\left(\mathrm{X}_{3}\right)$ memiliki hasil signifikan, sehingga hipotesis ketiga $\left(\mathrm{H}_{3}\right)$, yaitu terdapat pengaruh komitmen organisasional secara parsial positif dan signifikan terhadap kinerja karyawan pada RSIB diterima. Hasil penelitian tersebut mendukung hasil penelitian yang dilakukan oleh Anggraeni dan Rahardja (2018), yaitu komitmen organisasional berpengaruh positif dan signifikan terhadap kinerja karyawan. Selanjutnya, hasil tersebut juga memperkuat pendapat Moorhead dan Griffin (2013), yaitu komitmen organisasional merupakan sikap yang mencerminkan sejauh mana seseorang individu mengenal dan terikat pada organisasinya. Menurut Hunt dan Morgan (dalam Sopiah, 2008), karyawan memiliki komitmen organisasional yang tinggi, apabila mereka memiliki kepercayaan dan dapat menerima tujuan dan menilai organisasi, memiliki keinginan untuk berusaha ke arah pencapaian tujuan organisasi, dan memiliki keinginan yang kuat untuk bertahan sebagai anggota organisasi.

\section{KESIMPULAN DAN SARAN}

\section{Kesimpulan}

Berdasarkan hasil analisis yang telah dilakukan, maka kesimpulan dari penelitian ini adalah Disiplin kerja berpengaruh secara parsial terhadap kinerja karyawan pada RSIB yang dapat dibuktikan dari hasil signifikansi $0,000<0,05$ dan berdasarkan perbandingan $t_{\text {hitung }} 4,102$ lebih besar daripada $t_{\text {tabel }} 1,67528(4,102>1,67528)$. Lingkungan kerja berpengaruh secara parsial terhadap kinerja karyawan pada RSIB dengan pembuktian melalui hasil signifikansi $0,000<0,05$ dan berdasarkan perbandingan $t_{\text {hitung }} 4,102$ lebih besar daripada $t_{\text {tabel }} 1,67528(4,102>1,67528)$. Komitmen organisasional berpengaruh secara parsial terhadap kinerja karyawan pada Rumah Sakit Islam Banjarmasin yang dapat dibuktikan dengan hasil signifikansi 0,000 0,042 dan berdasarkan $t_{\text {hitung }} 2,084$ lebih besar daripada $t_{\text {tabel }} 1,67528(2,084>1,67528)$.

\section{Saran}

Hasil penelitian ini diharapkan dapat memberikan kontribusi akademis kepada berbagai pihak yang berminat dalam pengembangan sumber daya manusia, khususnya dalam pemahaman terkait pengaruh disiplin kerja, lingkungan kerja, dan komitmen organisasional terhadap kinerja karyawan. Selain itu, hasil penelitian ini dapat dijadikan sebagai masukan bagi pengguna karyawan, khususnya manajemen pada RSIB agar memperhatikan disiplin kerja, lingkungan kerja, dan komitmen organisasional ke arah prestasi kerja yang lebih tinggi. Rekomendasi dari hasil penelitian ini adalah disiplin kerja, lingkungan kerja, dan komitmen organisasional secara umum sudah dilaksanakan dengan baik. Namun, manajemen RSIB perlu mengoptimalkan ketiga variabel tersebut secara menyeluruh, mulai dari atasan hingga bawahan dengan memberikan bonus insentif atau jabatan terhadap karyawan berprestasi, karena hal tersebut akan memberikan motivasi kepada karyawan dalam melaksanakan kerjanya. 


\section{DAFTAR REFERENSI}

Anggraeni, D. A. \& Rahardja, E. (2018). Pengaruh Gaya Kepemimpinan Feminin, Motivasi Kerja dan Komitmen Organisasional Terhadap Kinerja Karyawan PT Leo Agung Raya, Semarang. Diponegoro Journal of Management, 7(4): 1-14.

Arep, Ishak, \& Tanjung, H. (2003). Manajemen Motivasi. Jakarta: PT. Gramedia Widiasarana Indonesia.

Edison, E., Anwar, Y., \& Komariyah, I. (2017). Manajemen Sumberdaya Manusia. Bandung: Alfabeta.

Fajar, S. A. \& Heru, T. (2010). Manajemen Sumber Daya Manusia Sebagai Dasar Meraih Keunggulan Bersaing. Yogyakarta: Bagian Penerbitan STIE YKPN.

Ghoniyah, N. \& Masurip (2011). Peningkatan Kinerja Karyawan melalui Kepemimpinan, Lingkungan Kerja, dan Komitmen. Jurnal Dinamika Manajemen, 2(2): 118-129.

Nitisemito, A. S. (2014). Manajemen Personalia. Jakarta: Ghalia Indonesia.

Hasibuan, M. (2009). Manajemen: Dasar, Pengertian, dan Masalah. Edisi Revisi. Jakarta: Bumi Aksara.

Husain, B. A. (2018). Pengaruh Disiplin Kerja Terhadap Kinerja Karyawan (Pada PT. Bank Danamon Tbk. Cabang Bintaro). Jurnal Ilmiah Manajemen Forkamma, 1(3): 130-138.

Likdanawati (2018). Pengaruh Pengalaman Kerja, Kompetensi dan Disiplin Kerja Terhadap Kinerja Pegawai di Rumah Sakit Umum Labuhan Haji Tengah Aceh Selatan. Jurnal Visioner \& Strategis, 7(1): 17-22.

Mangkunegara (2014). Manajemen Sumber Daya Manusia Perusahaan. Bandung: Remaja Rosdakarya.

Marwansyah (2016). Manajemen Sumber Daya Manusia. Bandung: Alfabeta.

Moorhead, G. \& Griffin, R. W. (2013). Perilaku Organisasi: Manajemen Sumber Daya Manusia dan Organisasi. Jakarta: Salemba Empat.

Murty, W. A. \& Hudiwinarsih. G. (2012). Pengaruh Kompensasi, Motivasi dan Komitmen Organisasional Terhadap Kinerja Karyawan Bagian Akuntansi (Studi Kasus pada Perusahaan Manufaktur di Surabaya). The Indonesian Accounting Review, 2(2): 215-228.

Pratama, Y. E. \& Wismar'ein, D. (2018). Pengaruh Pelatihan dan Lingkungan Kerja Terhadap Kinerja Karyawan. Business Management Analysis Journal (BMAJ), $1(1)$.

Rivai, V. \& Sagala, E. J. (2013). Manajemen Sumber Daya Manusia untuk Perusahaan: Dari Teori ke Praktik. Jakarta: PT Raja Grafindo Persada.

Robbins, S.P. \& Judge (2008). Perilaku Organisasi. Jakarta: Salemba.

Sedarmayanti (2014). Sumber Daya Manusia dan Produktivitas Kerja. Bandung: CV Mandar Maju.

Sedarmayanti. (2017). Manajemen Sumber Daya Manusia. Bandung: Refika Aditama.

Sopiah (2008). Perilaku Organisasi. Yogyakarta: Andi Offset.

Sugiyono (2017). Metode Penelitian Kuantitatif, Kualitatif, dan R\&D. Bandung: Alfabeta. 
Supomo, R. \& Nurhayati, E. (2018). Manajemen Sumberdaya Manusia. Bandung: Yrama Widya.

Sutrisno, E. (2014). Manajemen Sumber Daya Manusia. Jakarta: Pranada Media Group.

Tika, P. (2006). Budaya Organisasi dan Peningkatan Kinerja Perusahaan. Jakarta: PT Bumi Aksara.

Mamangkey, T. J., Tumbel, A., \& Uhing, Y. (2015). Pengaruh Pelatihan, Pengalaman dan Lingkungan Kerja Terhadap Kinerja Karyawan pada PT. Bangun Wenang Beverages Company Manado. Jurnal Emba, 3(1): 737-747.

Wirawan (2013). Kepemimpinan: Teori, Psikologi, Perilaku Organisasi, Aplikasi dan Penelitian. Jakarta: PT Raja Grafindo Persada. 